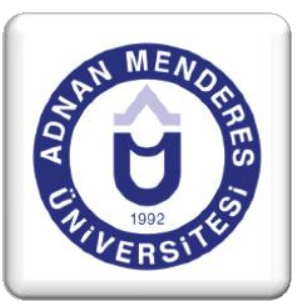

\title{
Somut Olmayan Kültürel Miras ve Üniversite Gençliği
}

Mehmet Surur ÇELEPİ ${ }^{1}$

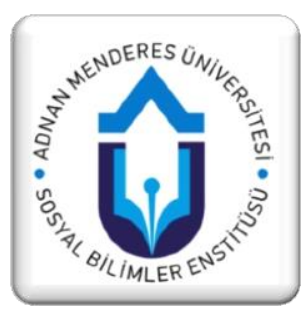

\section{ÖZET}

Küreselleşmenin milletlerin kültürel ifade çeşitliliğini ortadan kaldırdığını düşünen UNESCO, Somut Olmayan Kültürel Miras Sözleşmesi'ni hazırlayarak, toplumların kültürel kimliklerinin bir parçası olarak gördükleri ve kuşaktan kuşağa aktarmak suretiyle günümüze kadar getirdikleri somut olmayan kültürel miraslarını ve bu mirasları gelecek kuşaklara aktarmalarına katkı sağlayacak yol, yöntem ve imkânları korumayı hedeflemektedir. Sözleşmenin sınırlarını toplulukların, grupların ve kimi durumlarda bireylerin, kültürel miraslarının bir parçası olarak tanımladıkları uygulamalar, temsiller, anlatımlar, bilgiler, beceriler ve bunlara ilişkin araçlar, gereçler ve kültürel mekânlar olarak belirler. Birleşmiş Milletler ve alt örgütü UNESCO bu sözleşmeyi uluslararası alanda kültürel kimliğin hayati bir parçası olarak kabul eder ve yaratıcılığın geliştirilmesinin, kültürel çeşitliliğin korunmasının buna bağlı olduğunu belirtir. Türk gençliği son yarım yüzyılda küreselleşmenin etkisiyle kimliksiz bir şekilde gönüllü olarak sömürülmektedir. Bu çalışmada üniversite gençliğinin Türklerin Somut Olmayan Kültürel Miras değerleriyle ilgili farkındalıklarını ve bağlılıklarını tespit etmek, değerlere yaklaşımlarını belirlemek amaçlanmıştır. $\mathrm{Bu}$ çerçevede öğrenciler arasında bir anket düzenlenmiş ve sonuçlar değerlendirilmiştir.

Anahtar Kelimeler: Küreselleşme, Millî Kültür, Soküm, Üniversite Gençliği

\section{Intangible Cultural Heritage and University Youth}

\begin{abstract}
UNESCO, thinking that globalization abolishes cultural statements diversity of nations, by preparing Intangible Cultural Heritage Convention; aims to protect Intangible Cultural Heritage, which nations regard as a part of their cultural identities, intangible cultural heritage that they hand down from generations to generations by making them a current issue up to now,means,methods, and opportunities that contribute these heritage to transfer to the next generations. The limits of the convention is determined by the practises, which societies, groups, in some situations the individuals depict as a part of cultural heritage, representations, informations, skills, related devices, tools and cultural domains. The United Nations and its sub-committee UNESCO, approve this convention as a vital part of cultural identity in international area and indicate that developing the creativity and conserving the cultural diversity are related to it. Turkish Youth, having no identity, has been exploited voluntarily because of globalization in the last half century. In this study, it has been aimed to define the awereness of the university youth about the Intangible Cultural Heritage of Turks and determine their loyality and aproach to cultural values.In this framework,a survey was prepared among students and consequences were evaluated.
\end{abstract}

Keywords:Globalization,National Cultur,Soküm,University Youth

\footnotetext{
${ }^{1}$ Yrd. Doç. Dr., Pamukkale Üniversitesi, Fen-Edebiyat Fakültesi, Türk Dili ve Edebiyatı Bölümü, msururcelepi@gmail.
} 


\section{Giriş}

Kavimlerin ve milletlerin, medeniyet ve uygarlık seviyelerine ulaşabilmeleri için dünyaya bütüncül bakabilmeleri gerekir. Bu bütüncül yaklaşım devlet, siyaset, toplum, kültür, din, bilim ve sanatın uyumunu gerektirir. Bu yaklaşımda kültür-bilim-devlet üçlüsünün uyumunu önceleyenler dünyayı daha iyi algılar, evrensel değerleri yaratır ve böylelikle tarih sahnesinde daha güçlü olurlar.

Mustafa Kemal Atatürk'ün Türk gençliğine hitaben söylediği “Türk evladı ecdadını tanıdıkça daha büyük işler yapmak için kendinde güç ve kuvvet bulacaktır." şeklindeki vecizesi, dünyaya bütüncül bakabilmek için bir yol haritası hükmündedir. Zira bu vecizeye, sadece kurtuluş savaşını kazanan ulusun yeni çocuklarına, Türk askerinin gücünü gösteren ve bir iç dinamizm yaratması beklenen askerî veya tarihî bir söz olarak bakmamak gerekir. Atatürk, gençlerin yeni devletin inşasında ve kökleşmesinde ihtiyaç hissettikleri her şeyin kadim Türk medeniyetinde bulunduğunun farkındadır. Gençlerin muhtaç oldukları kudretin damarlarındaki asil kanda mevcut olduğunu bildiren Atatürk böylelikle, gençlerin kadim Türk uygarlığındaki kültürü, bilimi, sanatı, devlet ve toplum bütünleşmesini anlamaları gerektiğini bildirir.

Evrensel değerlere katkı yapan uygarlıklar seviyesine çıkabilmenin ilk şartı dünyayı algılamada millî kültürel değerleri öncelemektir. Uygarlık seviyesine ulaşmış bütün kavimler, dünyayı kendi kültürel hafıza ve bellekleriyle algılamışlardır. Bu algılayışta kültürel bağlılık son derece önemlidir. Türk gençlerinin de yarının inşasındaki bilimsel, sanatsal, toplumsal, siyasi ve sportif bütün faaliyetlerinde referanslarını kadim Türk kültüründen almaları gerektiği unutulmamalıdır.

Çünkü Kültür, kavimlerin geçmişten miras aldıkları ve hayatlarının her alanını düzenleyen maddi-manevi değerler bütünüdür. Millet kavramının temellerinden biri olan kültür, toplumun duygu ve düşüncelerinin, dünya ve unsurlarını anlama ve anlamlandırma sistemlerinin, var olma ve geleceğe taşınma kaygılarının insan ve doğa gerçeğinin birleşmesiyle şekillenmiştir. $\mathrm{Bu}$ bağlamda kültür ve insan arasında karşılıklı faydaya dayanan bir ilişki vardır. Kültür, aidiyet duygusuyla kendisine bağlı insanları enstrümanlarıyla korur ama nesilden nesile aktarımında ise insana muhtaçtır. Bu birliktelik, kültürden ziyade insanın menfaatinedir. Bir kültür dairesine bağlı olmak, beşeri yaşamını devam ettiren insanın işini kolaylaştırır, kendini güvende hissettirir. Örnekse, bir kültür dairesine mensup olmayan bir birey, biri öldügünde cesedi ne yapması gerektiği başta olmak üzere nasıl davranması gerektiği hususunda bir bilinmezlik yaşar. Binlerce yıllık deneyimle ölüm kültürünü miras alan bir birey ise bu bağlamda bir tedirginlik yaşamaz. Nasıl davranması gerektiği önceden bellidir.

Medeniyet ve uygarlık yolundaki her millet, binlerce yıllık ortak yaşam ve deneyimlerle yoğurduğu ve kristalize ederek oluşturduğu kültürel mirasını, gelecek kuşaklara aktararak, varlığının devamlılığını tesis etmeye çalışır. Bu süreçte evrensel değerleri içselleştirerek ve onlara yaşam alanı yaratarak kendi kültürel mirasını insanlığın ortak mirası seviyesine evirmeye çalışır. $\mathrm{Bu}$ durum medeniyetlere kültürel miraslarıyla dünyada ön planda yer almaları için imkân sağlar. Kendi kültürünün hem yerelliğini hem de evrenselliğini yaşayan birey, bu aidiyet duygusuyla birey olduğunun farkına varır ve bu kültürel miras içinde toplumsallaşır. Binlerce yıllık deneyim, birikim ve toplumsallaşma geleceği şekillendirip teminat altına alınca uygarlıkların kimlik ve ruhları belirlenmiş olur. Belirlenen toplumsal kimlik ve ruhlar millet olmanın şartlarıdır. 


\section{Somut Olmayan Kültürel Miras}

Dünya tarihi, sömüren ve sömürülen ülkeler hakkında sıklıkla bilgi verir. Sömürgeciliğin amacı her zaman daha fazla kaynak ve meta olsa da sömürme şekli yüzyılımıza yaklaştıkça değişmiş̧ir. Bizce son yıllarda dünya tarihi yavaş yavaş gönüllü sömürülme denilen olguyla tanışmaktadır. Dünya ekonomisinin büyük bölümünü ellerinde bulunduran ülkeler ve onlara bağlı ticari yapılar, daha fazla büyüyebilmek için yani bir anlamda sömürmek için eski sistemde olduğu gibi silahı ve şiddeti kullanmak yerine marka değerlerini artırmayı ve dünyada bunları yaygınlaştırmayı amaçlarlar. Böylelikle kendilerine bağımlılığı artırmayı hedeflerler. Bunu yaparken kendi kültürel değerlerini, bu ürünlerle beraber ihraç ederler. Kendi metalarının kullanılması için, kendi değerlerinin de gizlendiği suni bir kullanım kılavuzu hazırlarlar. Örnekse, bir yiyecek firması sadece bir yiyecek firması değildir. O yiyeceğin nerede, nasıl tüketileceği, hangi kültürün ürünüyse hangi dil ile yaygınlaşacağı, yani dil evreninin sınırları önceden belirlenmiştir. Çok cazip olarak sunulan ve çeşitli telkinlerle kullanımı alt belleğe çeşitli göndermelerle salık verilen bu ürünleri kullanırken kurallara uygun davranmayanlar çağdışı olmakla yaftalanır. Yaygınlık arttıkça, dünyada aynı şekilde beslenenlerin sayısı artar. Bu örnekte olduğu gibi zamanla bütün dünya insanları aynı şekilde eğlenmeye, evlenmeye, spor yapmaya, müzik dinlemeye, dans etmeye kısacası yaşamaya başlayıp kültürel anlamda tek tipleşirler. Gönüllü sömürülme burada başlar. Hazırlanan suni kılavuza uygun yaşayabilmek için gönüllü olarak tek tipleşilir ve kültürel miras göz ardı edilir.

Bahsedilen tek tipleşme için Benjamin Barber; "iletişim, eğlence ve ticaret yoluyla bir araya gelmiş bir McDünya, parıltıll, renkli bir gelecek, her yerde insanları hızlı müzikleriyle (MTV), hızlı bilgisayarlarıyla, hızlı yemekleriyle (McDonald's) büyüleyen ve ulusları türdeş bir küresel lunaparka girmeye iten, bütünleşme ve birlik isteyen ve saldırıya geçmiş ekonomik, teknolojik ve ekolojik güçlerin hareketli ortamı" benzetmesini yapar (Barber, 2013: 93). Anlaşıldığ1 kadarıyla tek tipleşme kavramı sosyologların aklına ilk olarak Amerika Birleşik Devletlerini getirmektedir. Hepsi açı piyasa ve küresel tüketimcilik ile ilintili olan Amerikan müziğinin, modasının, gıdasının, filmlerinin ve televizyonunun yaygın etkisi göz ardı edilemez. Bu etki sıklıkla "yumuşak güç olarak adlandırılan durumun yansımasıdır. Birleşik devletler hiç kimseyi bunları kullanması için zorlamaz. Fakat onlar yine devasa bir çekiciliğe ve tüketici cazibesine sahiptirler (Lieber ve Weisberg, 2013: 122).

Dünyanın en ücra köşelerine kadar yaygınlaşan tek tipleşme, ulusların kendi kültürel miraslarını yaşamalarına engel olur. Kültürel kimlik ve mirasların göz ardı edilmesi, kısa vadede belirginleşmese de uzun vadede toplumsallığın ve sosyal yapının etkinliğini azaltır. Zamanla dil başta olmak üzere değerlerin yok olduğu görülür. Örnekse, bir ulusun kültürünü, değerlerini, ileri görüşlülüğünü, deneyimlerini ve ince zekâsını en ince ayrıntısıyla yansıtan kalıp sözler (Kuşçu, 2015: 950) bile kullanılmaz olur. Bu durum dünya uluslarının dünyayı algılama yoluyla ortaya koydukları kültürel zenginliklerini azaltır ve yaratıcılıklarını törpüler. Bu törpülenme dünyayı dıştan içe aynılaştırır. Dıştan içe doğru, Dünyadaki bütün şehirler ve yaşam alanları yavaş yavaş aynı şekilde kurgulanmaya başlarken bu mekânları anlamlandıran insanlar da aynılaşır ve tek tipleşir. Bu durum küreselleşme, globalleşme kavramlarıyla açıklanır.

Özellikle sosyologlar küreselleşmeyle ilgili belirli kavramların öne çıktığı bazı tanımlar yaparlar. Örneğin "Küreselleşme, ekonominin ve enformasyon teknolojisinin, küresel entegrasyonun artmas1, popüler küresel kültürün ve değişik formlarda insan ilişkilerinin yaygınlaşmasıdır" (Lieber ve Weisberg 2013: 113) tanımı bunlardan biridir. Ama bütün tanımlarda ortak olan hususlar ekonomi, teknoloji ve popüler kültür kavramlarıdır. Küreselleşme, her yerde bu kavramlarla birlikte düşünülür ve sosyal kimlikler bütünüyle, 
böyle temel sosyal düzenlerin yeniden yapılandırılmasında rol alır. Bunlar her yerde metalaştırma, üretkenlik, finansal değer gibi olgularla kendilerini ifade ederler (Kalb ve Van der Land, 2013: 29).

Küreselleşme batı dünyasının zihin yapısıyla incelendiğinde "bir şeyi dünya ölçeğinde kılma, dünyaya mal etme" düşüncesi etrafinda yaygınlaş̧ı̆̆ı ve "bizde olanı dünyaya vermek, başkasından olanı almak" şeklinde açıklandığı görülür. Tanım böyle olsa da küreselleşme sürekli olarak batı kültürünü ve Hristiyanlık değerlerini alma fakat kendi değerlerini verememe olarak yaygınlaşmıştır (Oğuz, 2001: 6). Küreselleşme ile dünyanın toplumları arasında ve içinde benzerlikler artmaktadır. Fakat bu trend az sayıda ülkenin orantısız küresel güce sahip olmasını beraberinde getirmektedir (Mazrui, 2013: 191). Küreselleşme ve tek tipleşme etkisinde kalan toplumlar, kendi millî kültürel özelliklerini terk etmek zorunda olduğundan, bu toplumlara mensup olan insanlar hâkim kültürün temsilcisi toplumların kültürel özelliklerini aynı şekilde benimsemek durumundadır. Birçok alanda kendi karakteristiklerini terk etmek zorunda kalacaktır (Arslan, 2006a,: 712). Ünlü stratejist Hungtington bu durumu tehlikeli görür. Ona göre dünya siyaseti yeni bir safhaya giriyor ve tarihin sonu, globalizm ve tribalizm pistonlarının çekişmesi yüzünden millî devletlerin gerilemesi yaşanıyor (Huntington, 2013: 208). Bu durumda küreselleşme sürecinde trajik bir durum yaşayan millî kültürlerin, içinde bulundukları bu durumdan çıkış yolu, değer ve anlam yüklü kültürel temellerinin anlaşılmasına bağlıdır (Arslan, 2006b).

Bütün bunlar tek tipleşme veya globalleşmenin çok boyutlu ve uluslararası bir süreç olduğunu gösterir. $\mathrm{Bu}$ süreç, ekoloji, kültür, ekonomi, politika ve sivil alanlarındaki oluşumları yan yana, ancak birbirine indirgenemeyen bir şekilde içerir. Bu durum aynı zamanda uluslararası aktörleri ön plana çıkarır (Kayserili ve Satır, 2013: 307). Bu aktörler, ekonomik modernleşme süreci ve sosyal değişim insanları uzun yüzyıllar içerisinde yaşadıkları yerel kimliklerden koparmaktadır. Bu durum dünyayı daha güvensiz yapmaktadır (Bülbül, 2013: 6).

Dünyanın her tarafının tek tipleşmeye doğru ilerlemesi Birleşmiş Milletler örgütünü kaygılandırmış ve örgüte bağlı UNESCO 17 Ekim 2003 tarihinde 32. Genel Konferans1 sırasında "Somut Olmayan Kültürel Mirasın Korunması Sözleşmesi"ni imzalamıştır. Türkiye, 19 Ocak 2006 tarihinde konuyu TBMM'de görüşmüş ve 5448 sayılı Somut Olmayan Kültürel Mirasın Korunması Sözleşmesinin Onaylanmasının uygun bulunduğuna dair kanun kabul edilmiştir. Gerekli süreçlerin ardından 27 Mart 2006 tarihinde 45. ülke olarak sözleşmeye olmuştur.

UNESCO Somut Olmayan Kültürel Mirasın Korunması Sözleşmesini, bir toplumun kendi kültürel kimliğinin bir parçası olarak gördüğü ve kuşaktan kuşağa aktarmak suretiyle günümüze kadar getirdiği somut olmayan kültürel miraslarını korumasına ve gelecek kuşaklara aktarmasına katkı sağlayacak yol, yöntem ve imkânları olarak tanımlar ve sınırlarını toplulukların, grupların ve kimi durumlarda bireylerin, kültürel miraslarının bir parçası olarak tanımladıkları uygulamalar, temsiller, anlatımlar, bilgiler, beceriler ve bunlara ilişkin araçlar, gereçler ve kültürel mekânlar olarak sınırlandırır (Oğuz, 2013a: 105, 110). Sınırları biraz daha belirginleştirecek olursak sözleşmenin korumayı amaçladığı somut olmayan kültürel miras sözlü gelenekler ve aktarımlar, gösteri sanatları, toplumsal uygulamalar, ritüeller ve şölenler doğa ve evrenle ilgili bilgi ve uygulamalar ve el sanatları geleneği alanlarında belirlenmesine karar verilmiştir (Oğuz, 2013: 64). Unesco Somut Olmayan Kültürel Miras (SOKÜM) sözleşmesinde "somut olmayan" terimini özellikle kullanmıştır. "Somut olmayan" hem soyut hem de somuttan farklı bir terimdir. Örnekse nazar boncuğu somut bir üründür. UNESCO somut olan nazar boncuğunu değil, nazar 
boncuğu üretimini, el sanatını bu geleneğin yaşatılması gerektiğini somut olmayan olarak adlandırır ve koruma altına almayı planlar.

Birleşmiş Milletler ve alt örgütü UNESCO bu sözleşmeyi uluslararası alanda kültürel kimliğin hayati bir parçası olarak kabul eder ve yaratıcılığın geliştirilmesinin ve kültürel çeşitliliğin korunmasının buna bağlı olduğunu belirtir. Sözlü ve somut olmayan miras, kültürler arasındaki uyum ve hoşgörü içinde ulusal ve uluslararası gelişmede temel bir role sahiptir. Küreselleşme sürecinde, bu kültürel mirasın sayısız formu kaybolmakta veya kültürel tek-tipleşme, silahlı çatışmalar, turizm, endüstrileşme, kentleşme, göç ve çevre kirliliğinin tehdidi altında bulunmaktadır (Oğuz, 2013: 49-50).

Çeşitli küreselleştirme araçlarıyla kontrol altına alınan toplumlarının girilemeyen en önemli dünyaları kültürel kökleridir. Bunlar ne kadar bastırılır ve sindirilirse de bir şekilde fırsatını bulduklarında yeniden filizlenebilmektedirler. Çünkü bu kültürel kökler topluma ulus bilinci kazandıran unsurlardır. Bu unsurlar, bir ulusun veya ülkenin kültürel kimliğini oluşsturan, tanımlayan, destekleyen veya gösteren, bir ulus veya ülkenin "diğer" veya "öteki" olarak gördüğü uluslar veya ülkeler karsısındaki farklılığını ve varlığını belgeleyen, kültür tanımlamasının içine giren ve bütün ulusal yaratıları, kazanımları ve maddesel varlıkları ifade ederler (Arslan, 2006a: 712).

UNESCO'nun Somut Olmayan Kültürel Mirasın Korunması Sözleşmesi ile uluslararası bir farkındalık yaratmaya çalıştığı somut olmayan kültürel miras terimi altında toplanan unsurlar, daha önce "kendiliğinden" aktarılarak var olmaya devam eden ya da süreç içinde "kendiliğinden" kaybolan ürünlerdi. Bir toplumun içine doğmakla birlikte o toplumun kültürüyle kültürlenen birey için masalları, efsaneleri, kültürel değer yargılarını, inanışları, yeme içme, giyim biçimlerini öğrenmek o topluluğun bir bireyi olması dolayısıyla kendiliğinden gerçekleşen doğal bir süreçti (Teke, 2013: 32-33). Fakat son yüzyılda küreselleşmeyle beraber bu doğal süreç kesintiye uğramaya başladı. Çağdaş kentin kültür üretim ve tüketim biçimleri, "evrensel" ve "popüler" denilen iki alanın yok edici kıskacında insanlığın çok kültürlü doğasını bozmaya başladı. İşte UNESCO bu noktada her ülkenin kendi egemenlik alanındaki kültürel mirasını korumasını ve gelecek kuşaklara aktarmasını önceleyerek sözleşmenin gerekliliğini izah etmektedir. Çünkü somut olmayan kültürel miras, bu mirası yaratan ve koruyan toplumun sonra da bütün insanlığın ortak belleğidir. Bu ortak bellek, paylaşılan bir deneyim olarak tarihsel süreklilik içinde ortaya çıkmıştır ve bu birikime insanlığın gelecekte de gereksinimi olacaktır. Bu kültürel mirasın korunması ve gelecek kuşaklara öğretilmesi tarihsel bir sorumluluktur (Oğuz, 2013a,: 65, 73).

UNESCO bu sözleşmeyle "insansız korumadan insanla birlikte ve insanlık için koruma" anlayışına yönelmiştir. Sözleşmede "insan" kavramının öne çıkarılmasıyla kültürel mirasın korunmasında; "kültürel mirası üreten ustalara", "kültürel mirası taşıyan ve aktaran bireylere" ve de "kültürel mirasların aktarıldığı mekânlara" özel bir önem atfedilmiş ve "yaşatarak koruma" yöntemi benimsenmiştir (Ekici ve Fedakar, 2013: 51). Dondurarak bir korumadan değil aktararak yani yaşatarak bir koruma amaçlanmaktadır ki bu da somut olmayan kültürel mirasın kuşaklar arasında aktarımı ile mümkün olacaktır (Teke, 2013a: 36). $\mathrm{Bu}$ aktarımda, örgün eğitim alanları müfredatlarına somut Olmayan kültürel mirasın entegre edilmesi ve somut olmayan kültürel mirasın "potansiyel" taşıyıcılarının ve aktarıcılarının bu mirasla erken yaşlarda tanışmalarının sağlanması önem taşımaktadır (Oğuz, 2013b: 5).

$\mathrm{Bu}$ çerçeveden bakıldığında somut olmayan kültürel miras, geçmişle bu bağlantıyı kurmak için gençleri bunu en iyi başarabilecek anahtar olarak görür. Gençlerin somut olmayan kültürel miras konusundaki farkındalıkları, bu mirası aktarmaya gönüllükleri bu anlamda önem kazanmaktadır. Kültürel miraslarının korunmasına katkı sağlamak gençlere sadece 
bireysel ve grup kimliklerini doğrulayan bir aracı sağlamakla kalmaz, aynı zamanda yaratıcılıklarını geliştirmelerini ve ekonomik gelişmeleri için yeni firsatlara açık olabilmelerini sağlar (Teke, 2013b: 73). Bu yüzden Somut Olmayan Kültürel Mirasın Korunması Sözleşmesi'nde eğitim, kültürel mirası koruma yollarından biri olarak sunulur. Sözleşmede "Kimlik saptaması, belgeleme, araştırma, muhafaza, koruma, geliştirme, güçlendirme, yeniden canlandırma" gibi koruma yollarının yanında özellikle okul içi ya da okul dış1 eğitim aracılığıyla kuşaktan kuşağa aktarımın önemine dikkat çekilir (Somut Olmayan Kültürel Mirasın Korunması Sözleşmesi, 17 Ekim 2003, Madde 2.3).

Sözleşme'nin 14. Maddesi “Eğitim, Duyarlılı̆̆ın ve Kapasitenin Güçlendirilmesi” ile ilgilidir ve eğitimin nasıl olabileceğine yönelik fikirler içermektedir. Bunun için toplumun genelini ve özellikle gençleri hedefleyen eğitici, duyarlılığı arttırıcı ve bilgilendirici programlar düzenlemek, ilgili topluluklar ve gruplar içinde belirli eğitim ve yetiştirme programları düzenlemek, bilginin kuşaktan kuşağa geçişini okul dişı olanaklarla sağlamak biçimindeki ifadeler Sözleşmede eğitimle ilgili yapılması gereken faaliyetlerin içeriğine yönelik bakış açıları sunar (Somut Olmayan Kültürel Mirasın Korunması Sözleşmesi, 17 Ekim 2003, Madde 14).

\section{Somut Olmayan Kültürel Miras ve Üniversite Gençliğgi}

Kimlik sahibi olarak gelişmek, kimlikli bir millet olabilmek ve evrensel yapı içinde kimlikli değerlerle bir yer edinebilmek gibi önemli konularda, Türk milletinin ve Türk devletlerinin durusunu belirleyecek olan bilimsel açılımlar ve kurumlaşmalar henüz gerçekleşmemiştir. "Biz" olma özelliği veren farklılıklar temelinde biçimlenen millî bilincin ve kültürel mirasın ne olduğunu cevaplayacak çalışmalar yeterince ve gerektiği şekilde yapılamamıştır. Türk kültürünü kavrama, anlama ve anlatma yolları belirlenmemiş, binlerce yıllık değerler sistemi çağdaş yorumlarla günümüze taşınarak içselleştirilip ulusala ve evrensele yayılma yolunda doğru ve planlı adımlar atılamamıştır. Bütün bunların sonucu olarak, Türk insanı kitle kültürünün de yoğun telkinleriyle kültürsüzlüğe, yozlaşmaya doğru sürüklenmekte ve adeta kişilik ve kimlik bunalımları içinde yok olmaya mahkûm edilmektedir (Arslan, 2006a: 712713).

Bir ülkeye, ulusa veya topluma millî kimlik duygusu veren kültürel mirasların korunması ve gelecek kuşaklara aktarılması düşüncesi, küresel bir uygulama olarak bütün eğitim sistemlerinde yerini almaktadır (Oğuz, 2009: 8). Anlaşıldığı kadarıyla kültürel mirasın nesilden nesile aktarımı için eğitime ve gençlere büyük önem verilmektedir. Çünkü yapısında gençlik olgusunun her zaman hâkim olduğu bir toplum, sürekli bir dinamizm, akışkanlık, arayış, yenilik ve değişim arzusu içerisindedir. Gençler arasında sosyal yapıları sürekli kılmak ve benimsetmek ve onları biçimlendirmek için gelenekler önemli bir etkendir (Ekici, 2008: 37). Meseleyi sadece UNESCO'nun sahiplendiği bir anlaşmaya indirgeyemeyiz. Milletlerin var olma savaşındaki en büyük yardımcıları olan kültürel değerleri, ancak nesilden nesile aktarıldığında anlam bulur. Bu aktarımda gönüllü taşıyıcılara ihtiyaç vardır. Günümüz Türkiye'sine bakıldığında bu aktarımın gönüllü taşıyıcılarının giderek azaldığ 1 ve sağlıklı bir şekilde ilerlemediği görülecektir. Bu sorunun birçok nedeni olabilir. Ama bu çalışmada sadece gençlerin kültürel miraslarından habersiz oldukları, küreselleşme karşısında kendi kültürel değerlerini yaşama ve koruma bilgi ve azminden uzak oldukları ve Türk kültürüne ön yargıları üzerinde durulacaktır.

Durumu daha iyi tespit edebilmek için üniversite öğrencileri arasında bir anketin düzenlenmesine karar verildi. Anketin amac1 üniversite gençliğinin Türklerin Somut Olmayan Kültürel Miras değerleriyle ilgili farkındalıklarını tespit etmek ve değerlere 
yaklaşımlarını anlamaya çalışmaktır. Bu anket, Pamukkale Üniversitesi SBE'de doktora öğrenimi gören Cem AYHAN'a, okutman olarak görev yaptığı Süleyman Demirel Üniversitesi Gönen Meslek Yüksekokulu öğrencileri arasında yaptırılmıştır. Anket; 103'ü kız, 47'si erkek olmak üzere toplam 150 öğrenci ile yapılmıştır. Anketi üniversite öğrencileri arasında yapmamızın nedeni hem çocukluk hem de gençlik dönemlerinde kültürel miras değerleriyle ilgili birikimlerini tespit edebilmektir. Öğrencilerin birinci sınıf olmasına dikkat edilmiştir. Ankette SOKÜM (17 Ekim 2003, Madde 2) sözleşmesinde yer alan beş temel alan esas alınmıştır. Bunlar;

a) somut olmayan kültürel mirasın aktarılmasında taşıyıcı işlevi gören dille birlikte sözlü gelenekler ve anlatımlar

b) gösteri sanatları

c) toplumsal uygulamalar, ritüeller ve şölenler,

d) doğa ve evrenle ilgili bilgi ve uygulamalar

e) el sanatları geleneği

şeklindeki alanlardır. Anketteki soruların bazıları çoktan seçmeli bazıları ise doğrudan soru niteliğindedir. Anket, öğrencilerin eğilimlerini tespit etmeye yönelik olduğundan bazı sorularda birden fazla cevap vermelerine imkân verilmiştir. Bazı soruların hazırlanmasında Öcal OĞUZ (2013a)'un eserinde değindiği konulardan esinlenilmiştir. Öğrencilere beş temel alana göre sorulan sorular ve cevap dağılımları şu şekildedir.

\subsection{Somut Olmayan Kültürel Mirasın Aktarılmasında Taşıyıcı İşlevi Gören Dille Birlikte Sözlü Gelenekler ve Anlatımlar}

UNESCO bu başlık altında, ninni, mani, türkü, ağıt, bilmece, efsane memorat, masal, halk hikâyesi, fikra, deyim ve atasözü gibi kültürel ve sözlü değerleri ifade etmek ister. Bu bölümde gençlerin Türk kültür dünyasına ait bazı hatırlama figürlerini ne kadar bildikleri tespit edilmeye çalışılmıştır. Bu bağlamda Türk kültürüne ait hatıllama figürleri ile yabancı kültüre ait hatırlama figürleri bir arada verilerek gençlerin kendi kültürlerine ait hatırlama figürlerine ait farkındalıkları tespit edilecektir.

Mitolojiler, milletlerin yaratılma süresince karşılaştıkları unsurları anlamlandırmak amacıyla sordukları sorulara yine kendilerinin verdikleri cevaplarla oluşturdukları metinlerdir. Türk mitolojisine ait hatırlama figürleri, nesilden nesile aktarılarak, yeni durumlar karşısında evrilerek günümüze kadar ilerler. Bu bağlamda ilk olarak öğrencilere Türk mitolojisine ait figürleri tanıyıp tanımadıkları sorulmuştur; 
Şekil 1: Mitolojik Kahramanlar

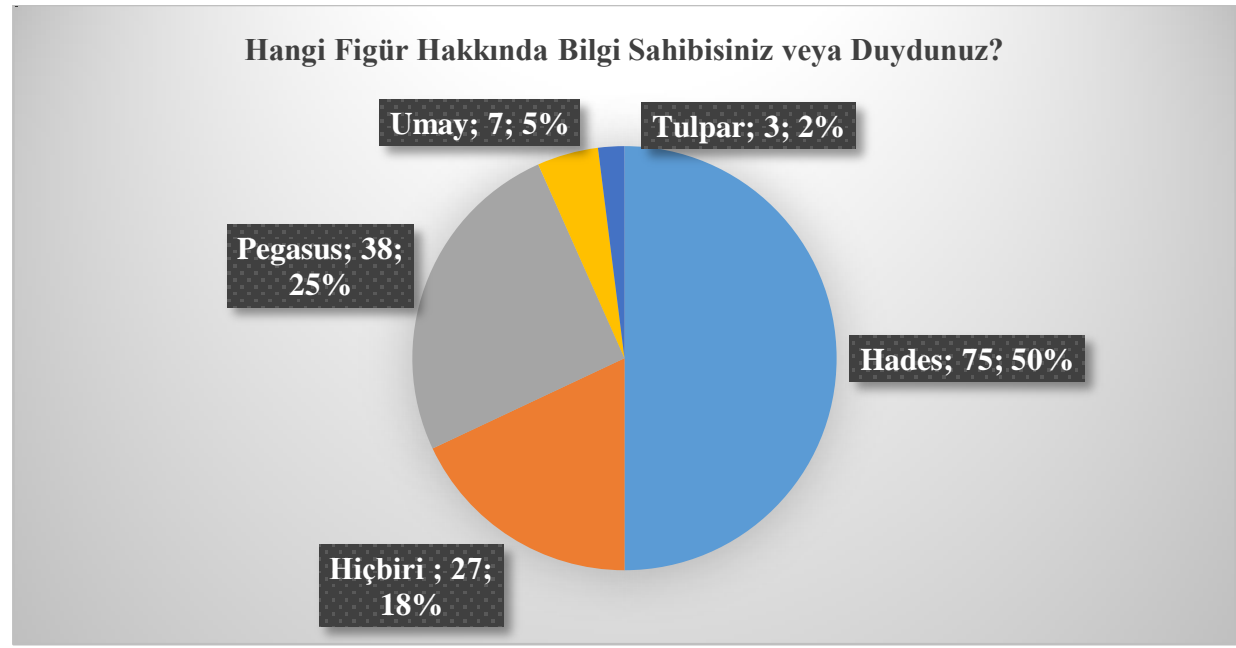

Grafikten anlaşıldığı kadarıyla Türk mitolojisinin önemli figürlerinden olan Umay ve Tulpar'1 toplam sadece 10 öğrenci duymuşken Yunan mitolojisine ait Hades'i 75 öğrenci tanıyor veya duymuştur. Bu durum şimdiki gençlerin çocukluk çağlarında izledikleri "Selena" adlı Türk yapımı diziyle ilintili olsa gerek. Öğrencilerin okul dönüş saatlerinde yayınlanan dizi, Türk yapımı olmasına rağmen Yunan mitolojisine ait figürleri, Türk çocuklarına izletmekte bir sakınca görmemiştir. O dönemi yaşayan her çocuk Hades'in Yunan mitolojisine ait kötülüklerin kahramanı olduğunu maalesef bilmektedir. Fakat eminiz ki sorular arasına Hades'in karşılı̆g 1 olan Türk mitolojisindeki Erlik'i koysak sonuç yine değişmeyecekti. Yine medya ve çeşitli Türk şirketlerin isim verirken hassasiyet göstermemeleri neticesinde Pegasus, Tulpar'dan 13 kat daha fazla bilinir durumdadır. Ankete katılan öğrencilerin üçte ikisi kız öğrenci olmasına rağmen, Türk mitolojisinde kadının ve çocuğun koruyucu ruhu Umay figürünü 143 öğrencinin duymamış olmaları son derece düşündürücüdür.

Destanlar, bir milletin var olma savaşlarının ve tarihteki köklü temsiliyetlerinin en önemli ürünleridirler. Bu bağlamda kimlik oluşumunda son derece önemli anlatılardır. Her ulus, kendi çocuklarına, kendi destanlarını hatırlama figürü olarak hatırlatır ve gerektiğinde buradaki kahramanlıklarla bir iç dinamizm yakalar. Bu çerçevede öğrencilere Türk destan kahramanlarını tanıyıp tanımadıkları yabancı kahramanların da olduğu bir soruyla tespit etmeye çalış1dı. 
Şekil 2: Destan Kahramanları

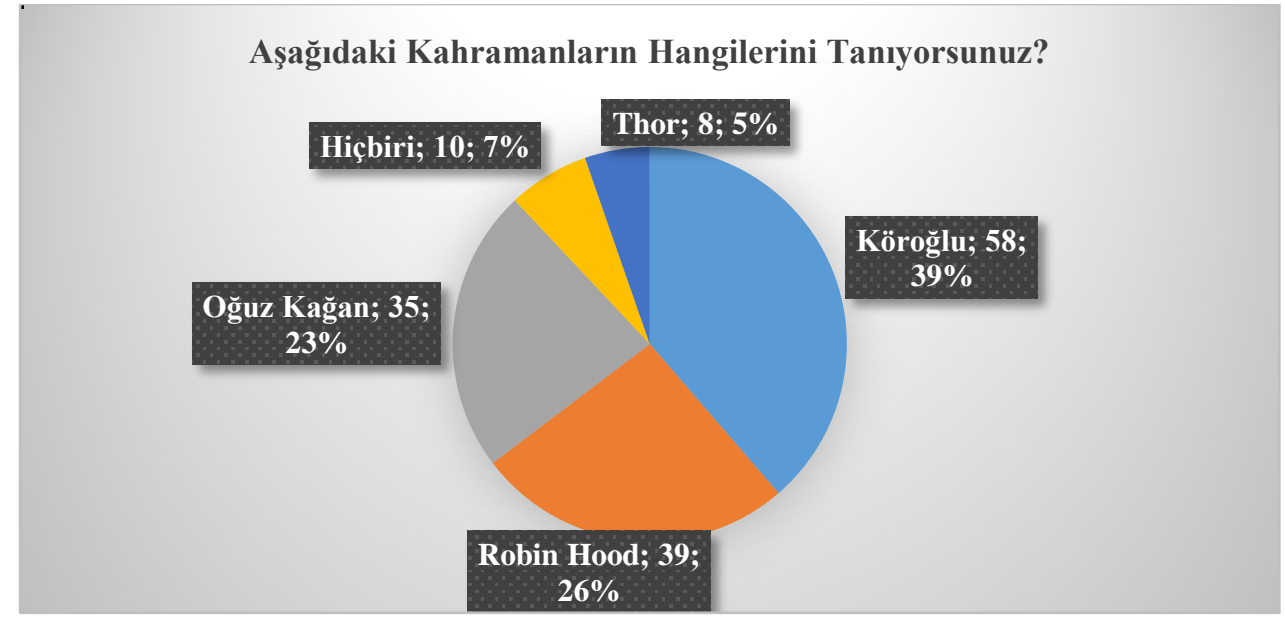

Ankete katılan öğrenciler Robin Hood adlı karakteri Oğuz Kağan'dan daha fazla tanımaktadırlar. Oğuz Kağan destanı Türklerin en köklü destanıyken, maalesef öğrencilerimiz İngiliz bir haydudu Oğuz Kağan'dan daha fazla tanımaktadırlar. Bu durum yine medyanın diğer uygarlıklara ait kahramanları ön plana çıkarmasıyla ilintilidir. Köroğlu'nun sinemalara aktarılmış olması onun gençler arasında tanınırlığını artırmıştır. Dikkat çeken bir ayrıntı ise 57 kişinin ne Köroğlu'nu ne de Oğuz Kağan'ı tanımalarıdır.

Halk hikâyeleri Türk kültürünün önemli anlatılarındandır. Konusu genellikle aşk ve kahramanlık olan halk hikâyeleri, hem metin hem de icra ortamları bakımından SOKÜM'ün önemli başlıklarındandır. Öğrencilere büyük aşkların temsilcileri niteliğindeki Türk ve yabanc1 karakterlerin hangilerini bildikleri soruldu.

Şekil 3: Hikâye Kahramanları

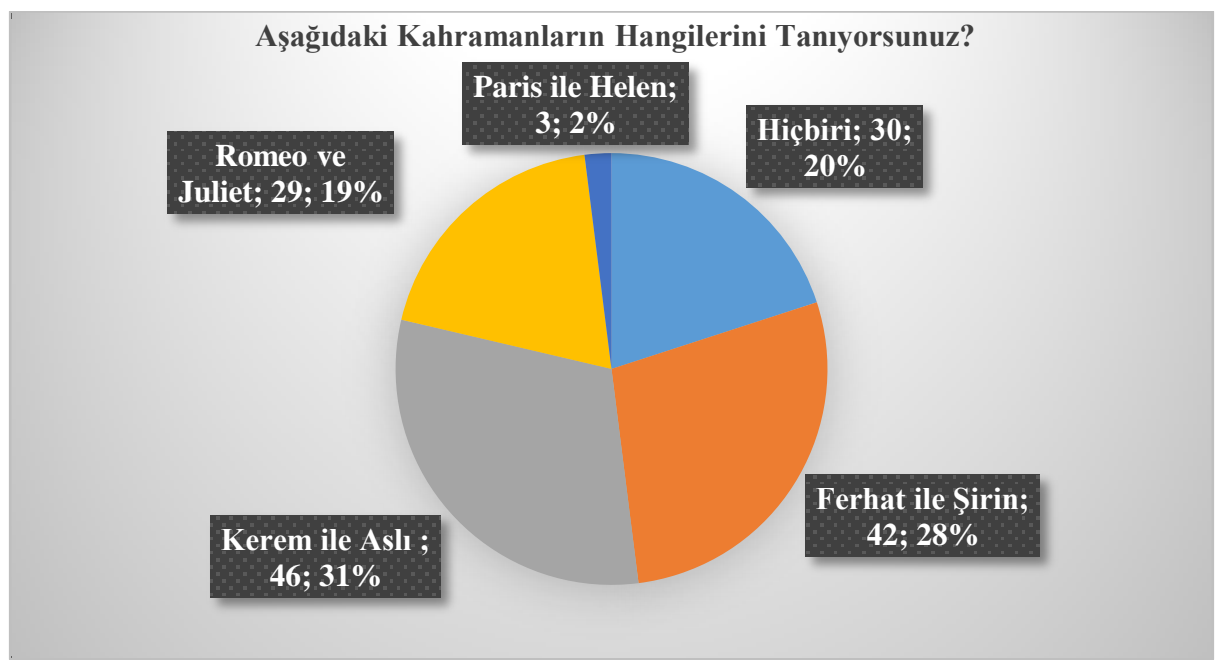

Grafiğe bakıldığında büyük bir oranda Kerem ile Aslı, Ferhat ile Şirin'i bilmeyen öğrencilerin olduğu görülse de en bilinen kahramanlar yine Ferhat ile Şirin, Kerem ile Aslı'dır. Bu grafikte yine 30 kişinin aşk yolculuğunun yorulmaz kahramanlarından Ferhat ile 
Şirin'i; Kerem ile Aslı'yı bilmiyor olmaları üzüntü vericidir. Halk romantizminin yansıması olan hikâyeler günümüz romanlarının, sinema ve dizi filmlerinin işlevlerini yerine getirmişlerdir. Bu kadar önemli hikâyelerin sadece 88 kişi tarafından biliniyor olması, öğrencilerin millî romantizme yakın olmadıklarının işaretidir.

Birer edebî halk sanatı olan masallar aracılığıyla çocukların bilinçaltına göndermeler yapılır. Sağlam ve sağlıklı bir ruh yapısının oluşumunda masallar çocuklara dolaylı göndermelerle yardımc1 olur (Önal, 2011: 6, 8). İçerdikleri örtük mesajlarla çocukların birey olma süreçlerine destek olan masallar, SOKÜM'ün en önemli alanlarındandır. Külkedisi, Keloğlan, Kırmızı Başlıklı Kız, Zümrüdü Anka ve Hiçbiri şıklarının olduğu ve hangisiyle ilgili masalı bildiklerinin tespit edilmeye çalışıldığı soruya verilen cevaplara aşağıdaki grafikte yer verilmiştir;

Şekil 4: Masal Kahramanları

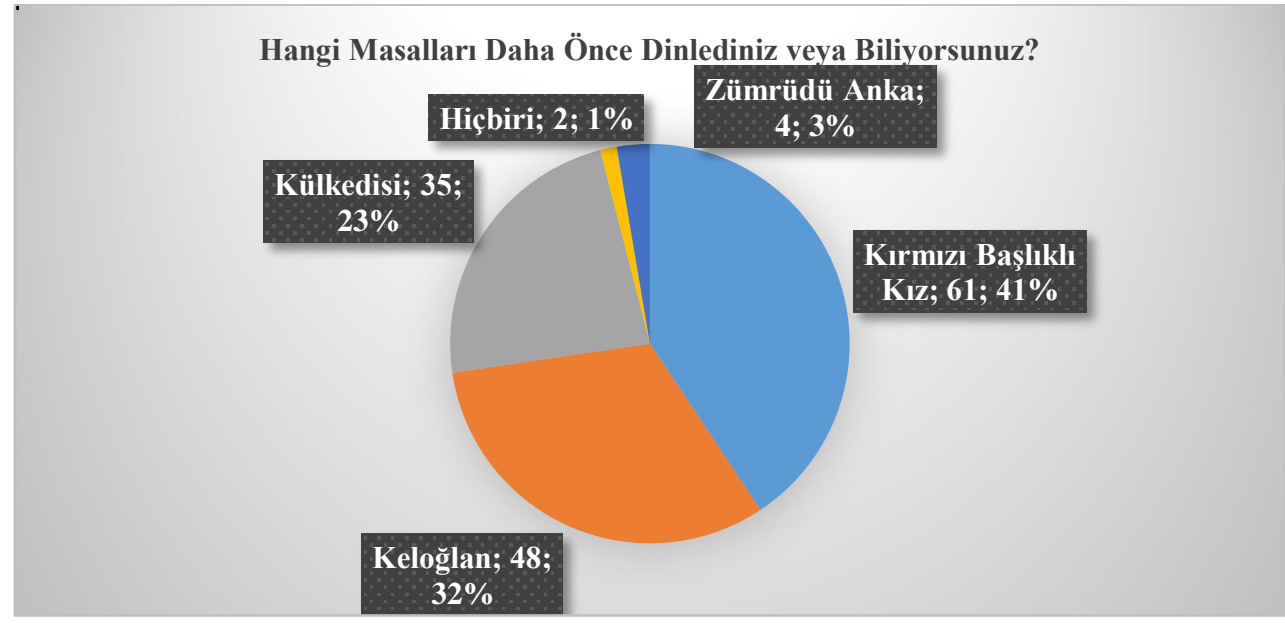

Grafikte en yüksek oranla (61 kişi, \%41) Kırmızı Başlıklı Kız cevabı verilmiştir. Maalesef Türklerin en bilindik masal kahramanı Keloğlan'1 ve Zümrüdü Anka masalını bilenlerin toplam sayısı, Kırmızı Başlıklı Kız masalını bilenlerin sayısına ulaşamamıştır. Türk masal kahramanlarının yerini tek tipleşme sayesinde genelleşen ve psikanalizcilerin birçok alt mesaj içerdiğini iddia ettikleri Kırmızı Başlıklı Kız masalı almıştır. Bu durum, Kırmızı Başlıklı Kız masalının endüstriyel olarak marka değerinin Keloğlandan daha yüksek olduğunun göstergesidir. Bugün sıradan bir kitapçıda Kırmızı başlıklı Kız, Pamuk Prenses ve Yedi Cüceler, Külkedisi adlı masalların kitapları ve boyama kitaplanı Türk masal kahramanlarının kitaplarına göre daha çok satılmaktadır. Anaokullarının ve ilköğretimlerin yılsonu gösterilerinde veya çeşitli etkinliklerde öğrencilere bu karakterlerin kıyafetleri, pelerinleri giydirilmekte ve bunda bir sakınca görülmemektedir. Hâlbuki her masal yaratıldığı kültürden damıtılmış kültürel bellek ögelerini barındırır. Bunlar aynı zamanda birer hatırlama figürleridirler.

$\mathrm{Bu}$ sorudan sonra öğrencilerin kaç masal bildikleri tespit edilmeye çalışılmıştır. 
Şekil 5: Bilinen Masal Sayısı

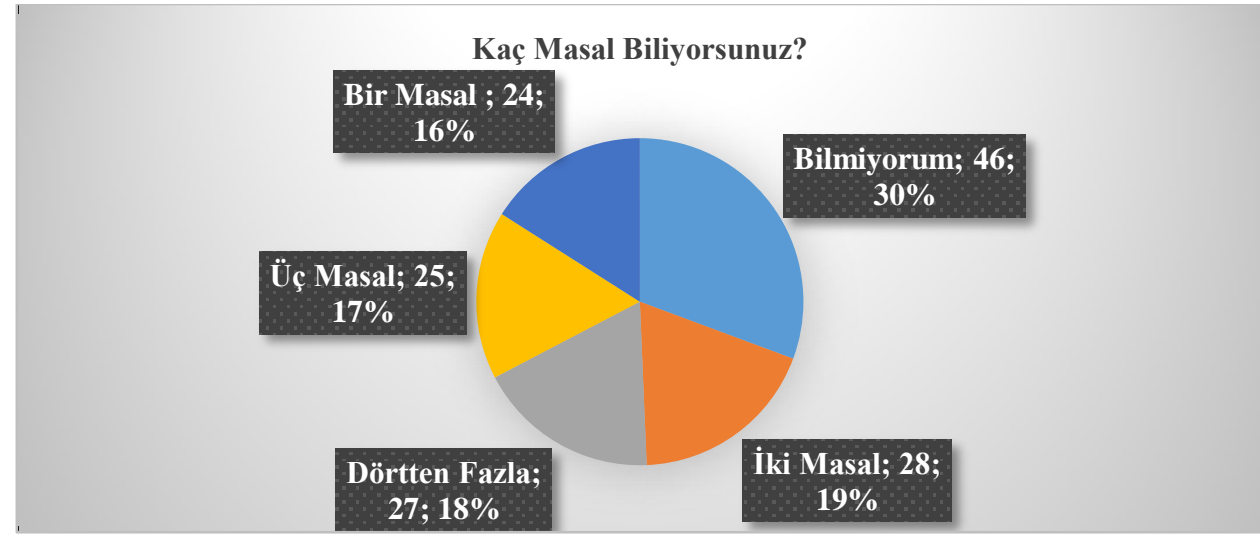

Grafikten anlaşılacağı üzere 46 öğrenci hiç masal bilmediğini ifade etmiştir. 150 katılımcının 103 'ünün kız öğrenci olduğu düşünüldüğünde masal bilmeyen öğrencilerin çoğunun kız öğrenci olduğu belirginleşir. İleride anne olacağı düşünülen öğrencilerin bir masal dahi bilmemeleri, Türk kültürü için son derece tehlikelidir. Bu sorunun ikinci aşamasında bildikleri masalları yazmaları istenmiştir. Yazılan birçok masal ise Türk masalı değildir. $\mathrm{Bu}$ durum tablonun vahametini artırmaktadır. Son çeyrek asırda Türk aileleri çocuklarını televizyonlara emanet etmiş durumdadır. Beslenme anından uyuma anına kadar çocuklar televizyondaki dünyanın sunumlarıyla baş başa kalınca hem beslenmede hem de diğer durumlarda dikkatleri dağıldığı için sessizleşir ve sakinleşirler. Daha az çaba sarf ettikleri için bu durum ailelerin hoşuna gidiyor olabilir. Ama masalın, annenin dilinden çocuğun beynine giden efsunlu bir öğreti yolu olduğu asla unutulmamalıdır.

Efsaneler, halkın inanma ihtiyacıyla olgunlaşan önemli kültürel anlatmalardır. Halkın mitlerle başlattığı yaratma gelenek ve güçlerinin evrilerek devam ettirilmesiyle oluşurlar. $\mathrm{Bu}$ efsanelerin bazıları taşlarla ilgilidir. Yapıları ve biçimleri bakımdan ilgi çekici taşlara ve kayalara, birtakım olağanüstülükler yüklenerek neden o şekilde oldukları efsanelerle izah edilir (Önal 2005: 49). Masallardan sonra, öğrencilere "Taş Kesilme" ile ilgili bir efsane örneği verilmiş ve bu efsaneyi daha önce duyup duymadıkları sorulmuş. Öğrencilerin 74'ü benzer bir efsane bildiklerini aktarırken 76's1 buna benzer bir efsaneyi daha önce duymadıklarını ve bilmediklerini ifade etmişlerdir. Çıkan oran gayet düşündürücüdür. Daha çok kırsaldan gelen ve kırsalda okuyan öğrencilerin yarısının benzer efsane duymamış olması Türk hayal sistematiğinden uzak olduklarının kanıtıdır.

Şiir ve müzik millî kültürün en önemli yansımalarıdır. Bir milletin duygu, düşünce, hayal, istek ve arzuları en çok bu ürünlere yansır ve bu ürünlerle aktarılır. Bu çerçevede Öğrencilerin Türk müziği ile ilgili farkındalıklarını ölçmek için çeşitli Türk sanatçıların olduğu bir soru yöneltilmiş hangisini dinlemeyi tercih edecekleri sorulmuştur. 
Şekil 6: Türk Müzisyenler

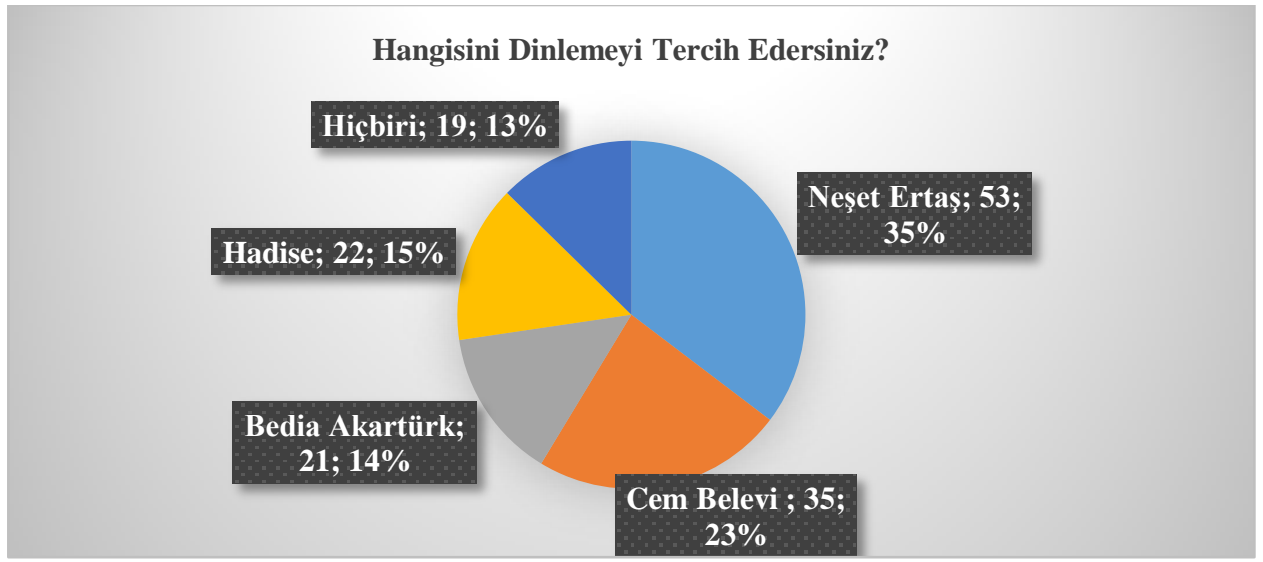

Görüldüğü üzere öğrencilerin büyük çoğunluğu Neşet Ertaş’1 diğer iki popüler sanatçıya karşın daha fazla dinlemeyi tercih edeceklerini belirtmişlerdir. 150 öğrenciden sadece 53'ünün Neşet Ertaş'1 dinlemeyi tercih etmesi düşündürücüdür. Yakın bir tarihte vefat etmesi, ölümünden sonra medyanın ve devletin ona olan ilgisi, kırsal kesimlerde çok tanınıyor olması çerçevesinde dinleyen kişi sayısının daha yüksek olması beklenirken az sayıda kişi tarafından dinlenmektedir. Gençlerin dinlediği Türk sanatçılar, belirli müzik şirketlerinin belirlediği şekillerde, belirli ritimlerin üstüne anlamsız sözler yazarak Türk müziğini nitelik olarak zayıflatmaktadırlar.

\subsection{Gösteri Sanatları}

SOKÜM bu başlık altında, âşıklık sanatı, köy seyirlik oyunları, karagöz, meddah gibi gösteri sanatlarını korumayı esas alır. Bu çerçevede öğrencilere farkındalıklarının tespiti için âşıklık geleneği ile ilgili olarak Şeref Taşlıova, Sümmani, Murat Çobanoğlu gibi sanatçıların hangi sanat dalı ile ilgili olabilecekleri sorulmuştur.

Şekil 7: Saz Şairleri

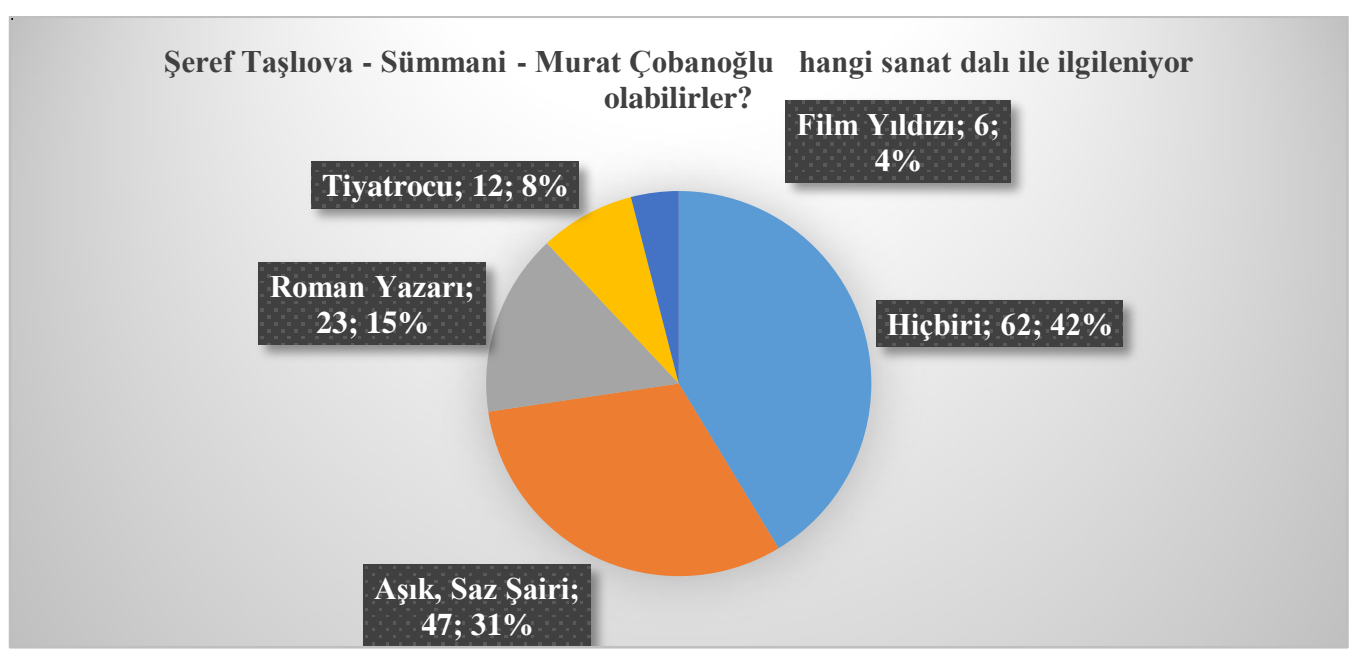


$\mathrm{Bu}$ sanatçıların ismi tercih edilirken yakın bir tarihte yaşayan veya en çok bilinebilecek isimler esas alınmıştır. Âşık unvanları özellikle kullanılmamıştır. Türk saz şiirinin ve âşıklık geleneğinin sanatçılarını sadece 47 öğrenci tanımıştır. 103 öğrenci bu sanat geleneğinin temsilcilerini tanımamaktadır. Kitle iletişim araçlarının artmasıyla beraber, Türk müziğinin, tiyatrosunun ve gösteri sanatlarının en önemli icracıları olan âşılar ve âşıklık geleneği unutulur olmuştur. Öğrencilere verilen isimler bu geleneğin son yüzyıldaki önemli temsilcileridir. Ona rağmen öğrencilerin üçte ikisi bu geleneği ve bu sanatçılarımızı tanımamaktadır.

Türk sanatçılarının tanınıp tanınmadığı ile ilgili diğer bir soru UNESCO'nun "İnsan Hazineleri”" adlı projesiyle ilgilidir. Öğrencilerin, "UNESCO hangilerini koruma altına almış olabilir?" sorusuna verdikleri cevaplar aşağıdaki grafikte verilmiştir.

Şekil 8: İnsan Hazineleri

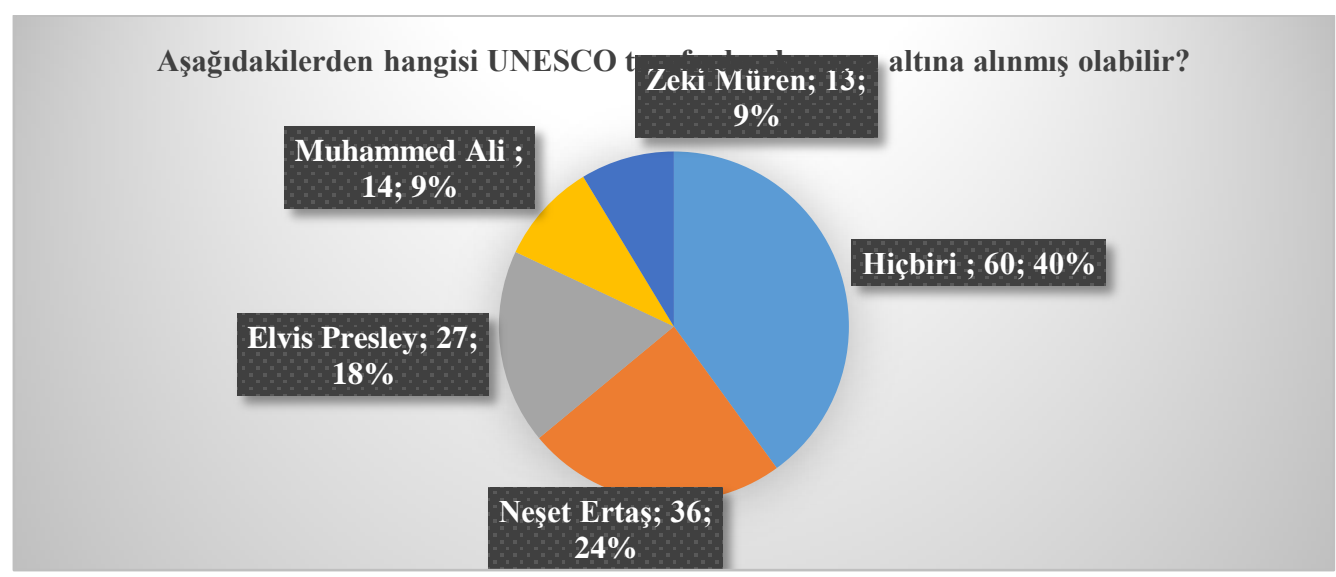

Anlaşıldığı kadarıyla öğrencilerin çoğunluğu Türk sanatçıların UNESCO tarafından koruma altına alabileceğine inanmamaktadır. Neşet Ertaş, UNESCO tarafından "İnsan Hazinesi" olarak belirlenmiştir. Fakat ankette Elvis Presley ve Neşet Ertaş arasındaki fark çok azdır. 41 öğrenci yabancıların koruma altına alınmış olabileceğini düşünürken sadece 49 öğrenci Türk sanatçıların koruma altına alınmış olabileceğine inanıyor. 101 öğrenci UNESCO'NUN bir Türk sanatçıyı koruma altına almış olabileceğine inanmıyor. Bu durum bu bölümün başında ifade edildiği gibi, gençlerin Türk kültürüne karşı ön yargılı davranmalarıyla ilintilidir.

\subsection{Toplumsal Uygulamalar, Ritüeller ve Şölenler}

SOKÜM bu başlık altında doğum, evlenme, ölüm, Hıdrellez, Mayıs yedisi gibi toplumsal uygulamaları, ritüel ve şölenlerin korunmasını ve gelecek nesillere aktarılmasını ifade eder. Bununla ilgili olarak öğrencilere çeşitli sorular sorulmuştur. Bazıları geçiş dönemi ile ilgiliyken bazıları ritüel ve törenlerle ilgilidir. Öğrencilere öncelikle doğum törenleriyle ilgili aşağıdaki grafikte yer verilen soru yöneltilmiştir. 
Şekil 9: Geçiş Dönemi Ritüelleri

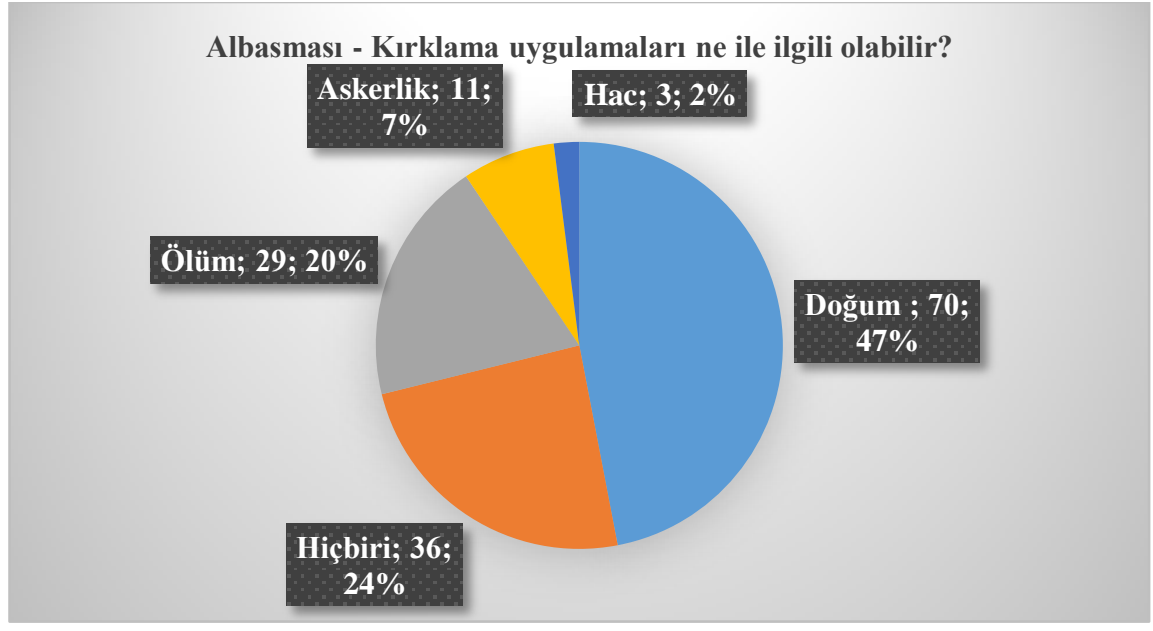

Türk kültüründe geçiş dönemi törenleri yavaş yavaş değişmeye ve tek tipleşmeye başlamış olsa da doğum gibi kutsal sayılan bir olayla ilgili törenler değişime biraz daha kapalıdır. $\mathrm{Bu}$ çerçevede yukarıda grafikte öğrencilerin yarısına yakını doğumla ilgili törenlerin farkındadırlar. Fakat bu durum üzüntü vericidir. Daha önce aktarıldığı gibi ankete katılan 150 öğrencinin 103'ü kız öğrencidir. Kadınlarla ilgili albasması, kırklama gibi terim ve uygulamalardan kız öğrenciler haberdar değildirler. Yine bir geçiş dönemi olan evlilik törenlerindeki uygulamaların yerini yabancı kültürlere ait uygulamaların almaya başladığını aşağıdaki grafik gözler önüne sermektedir.

Şekil 10: Geçiş Dönemi Törenleri

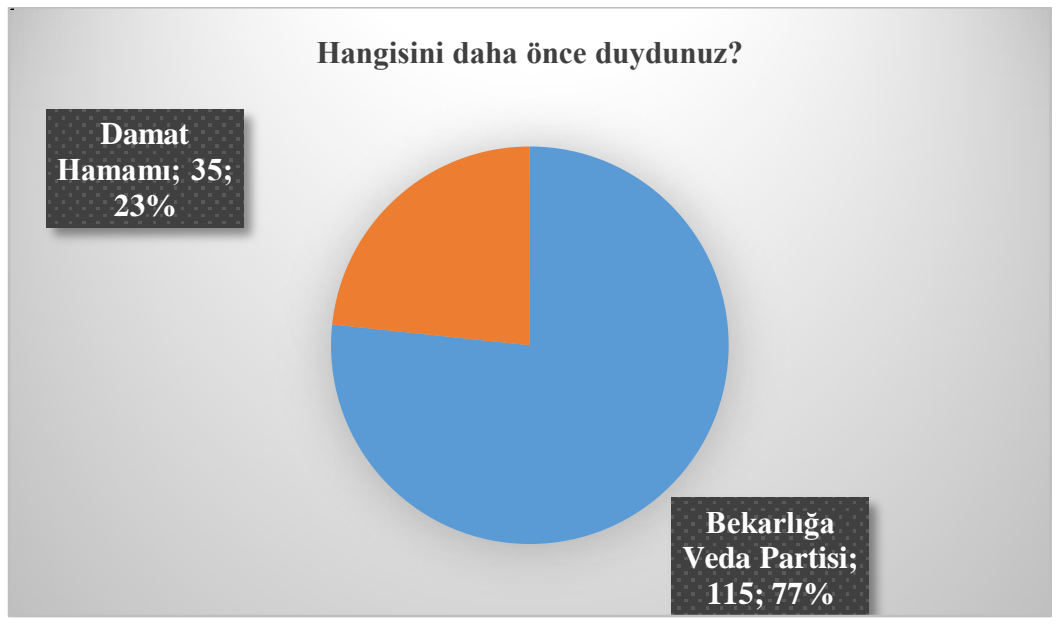

Grafik bize çok vahim sonuçlar vermektedir. Medyanın, yabancı dizi ve kültürlerin sayesinde damat hamamının yerini yavaş yavaş bekârlığa veda partisi almaya başlamış durumdadır. Gençler arasında bu uygulama yavaş yavaş yaygınlaşmaya başlamış durumdadır. Anadolu'nun birçok yerinde düğün öncesinde damat ve arkadaşlarının eğlencesi isim ve içerik değiştirmeye başlamıştır. Bunun tek sebebi medyanın cazip halde sunduğu, damat ve erkek arkadaşlarının katıldığı sınırları olmayan eğlencelerdir. Bu eğlencelerin 
içeriği Türk töre ve ahlak yapısına uygun değildir. Birçok dizide Tük aile yapısına uygun olmayan sahneler yerleştirilmekte, binlerce yıllık Türk kültürü yok sayılarak gençlerin dimağları yabancı kültürlerin değerleriyle işgal edilmektedir.

Geleneksel ritüel ve törenlerle ilgili yapılan incelemelerde bazı törenlerin öğrenciler tarafından bilindiği fakat yeterli bağlılığın olmadığı görülmüştür. Aşağıdaki grafik bunu doğrular niteliktedir.

Şekil 11: Dinî Törenler

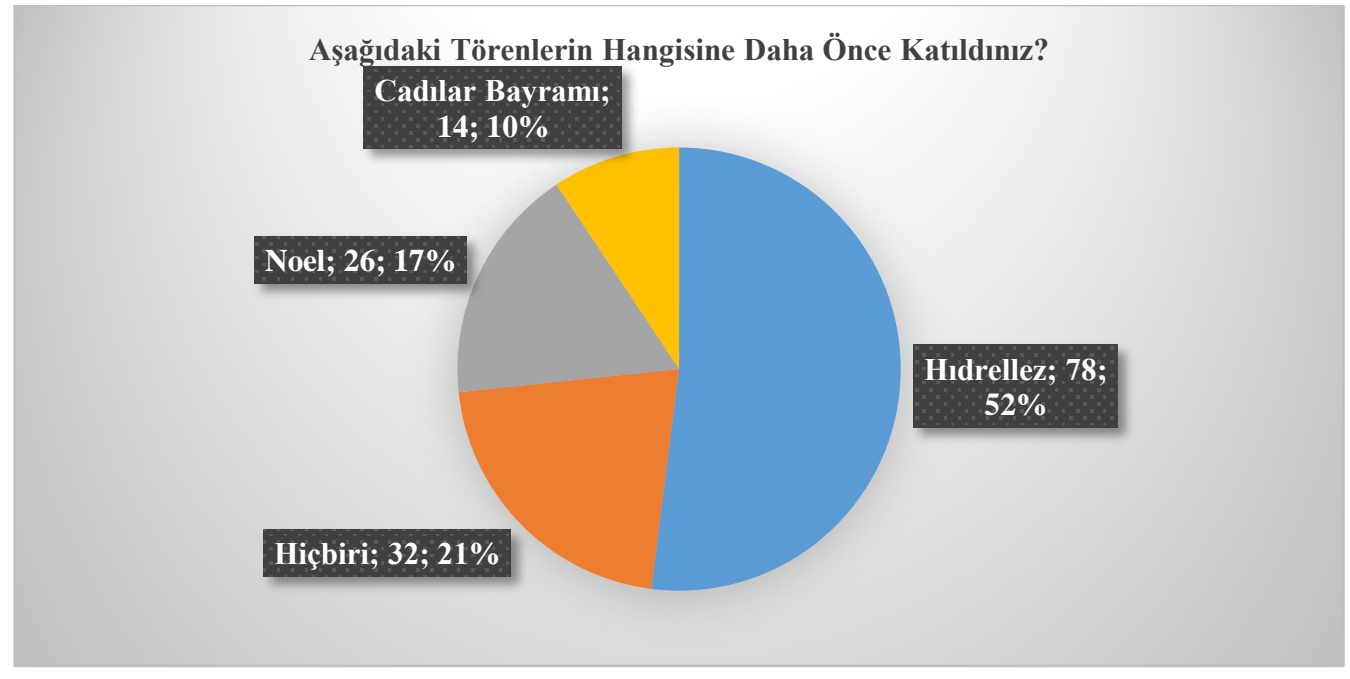

Grafiğe bakıldığında diğer dinlere ait cadılar bayramı, Noel gibi kutlamaların giderek Türk Kültürünün içerisine yerleştiği görülmektedir. 31 Ekim'de kutlanan "Cadılar Bayramı", ilk önceleri İstanbul, Ankara, İzmir gibi büyük şehirlerde yaşayıp da sosyoekonomik düzeyi yüksek kesimlerde kutlanırken, kitle iletişim araçları sayesinde toplumun hemen her kesimi tarafından bilinen ve büyük şehirlerin dışında da yaygınlık kazanmaya başlayan bir kutlama niteliği kazanmıştır. Cadılar Bayramı (Halloween), köken itibariyle tarım kültürünün bir ürünüdür. Nitekim yaz sonuna rastlayan bu dönemde hasat kaldırılmış, kış için gerekli hazırlıklar yapılmış olmalıdır. Kutlamalarda oynanan oyunlarda elmanın, findığın, şalgamın ya da bal kabağı gibi topraktan elde edilen ürünlerin kullanılması, Cadılar Bayramı'yla tarım işleri ve mevsim geçişleri arasındaki ilişkiyi göstermektedir. Tarihsel süreç içerisinde halloween adı verilen kutlama inanç ve pratikler açısından zenginleşmiş son aşamada da pagan dönemlerden kalan bu ritüeller dinî motiflerle birleştirilerek Hristiyanlık içerisinde yerini almıştır (Coşkun ve Zöhre, 2014: 501-502). Üzülerek görüyoruz ki 150 öğrencinin 14'ü cadılar bayramı adlı bu törene başka bir dine ve kültüre ait olduğuna bakmaksızın veya farkında olmaksızın katılmıştır. Hıdrellez'e katılımın bir nebze de olsa yüksek olması öğrencilerin daha çok kırsal bölgelerde yaşayan öğrenciler olmasıyla ilintilidir.

Yukarıdaki grafik törenlere katılım durumlarıyla ilgiliydi. Aşağıdaki grafik ise katılmasalar da bazı törenler hakkında bilgi sahibi olup olmadıklarını ölçmeye yöneliktir. 
Şekil 12: Geleneksel Törenler

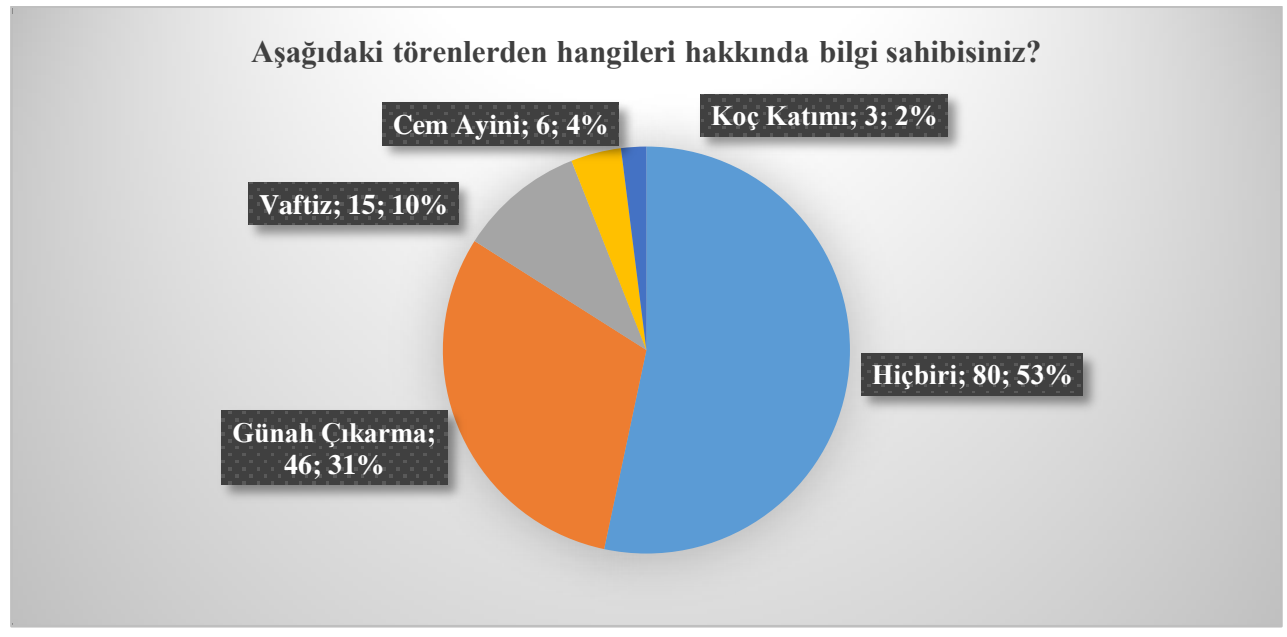

Grafiğe bakıldığında 150 öğrencinin sadece 9'unun katılmasalar da geleneksel törenler hakkında bilgi sahibi oldukları görülecektir. Yine farklı bir dine ait kültür değerleri hakkında ise büyük bir oranla bilgi sahibi oldukları görülmektedir. Cem ayini gibi önemli bir ritüel hakkında sadece 6 öğrencinin bilgi sahibi olması çok vahimdir. Geleneksel mevsim bayramlarından koç katımı hakkında sadece üç öğrenci bilgi sahibidir. Fakat batı ve Hristiyanlık dünyasının kültürel değerleri, televizyon ve internet sayesinde evlerimize girmektedir. Gençlerin çoğu diğer dinlere ait bu kutsal törenleri biliyor durumdadır. Gençlerimiz beşeri ilişkilerinde de referanslarını batı dünyasının değerleriyle oluşturmaya başlamışlardır. Örnekse, Türkçede ve Türk kültüründe bir kişi öldügü zaman geride kalanların acılarını paylaşmak ve hafifletmek için söylenebilecek onlarca güzel söz varken, maalesef çocuk ve gençlerimiz medyanın etkisiyle Hristiyanlık inancı olan "Toprağ 1 bol olsun" tabirini kullanmaktadırlar (Oğuz, 2013a)

Öğrencilerin çocukluk ve gençlik yıllarında oynadıkları oyunları tespit etmeye yönelik sorulara verdikleri cevaplar, modern şehirlerin, belediyelerin ve yöneticilerin çocukların geleneksel oyunları oynayabilmeleri için gerekli ortamı hazırlamadığını, çocukların oyun salonlarına yönlendirildiğini göstermektedir. Bununla ilgili grafik aşağıda verilmiştir. 
Şekil 13: Oyunlar

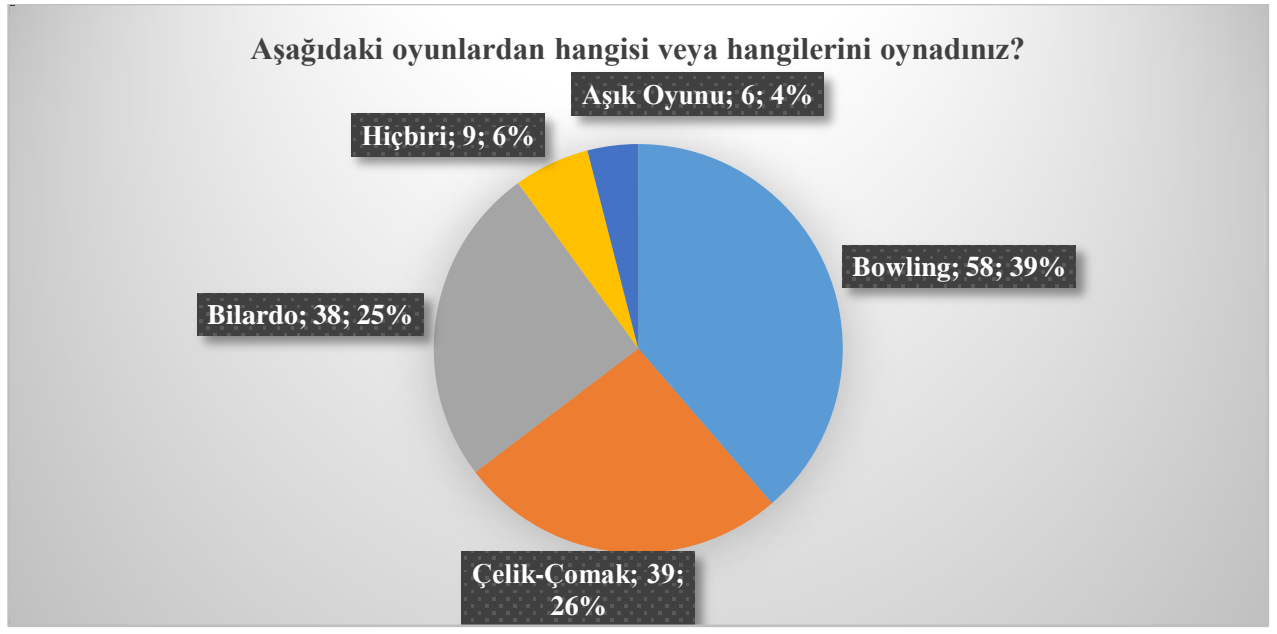

Üniversite gençlerinin çoğunluğu, geleneksel oyunları çocukken oynamadıklarını ama büyümeyle beraber Türk kültürüne ait olmayan salon oyunlarını yüksek oranda oynadıklarını belirtmişlerdir. Yine medya aracılığıyla bowling oyunu ön plana çıkarılarak cazibesi artırılmıştır. Türkiye'de son zamanlarda alışveriş merkezlerinin artmasıyla beraber, bowling salonlarının sayısında hızlı bir artış olmuştur. Alışveriş merkezleri sundukları hizmetlerle cazibelerini artırırken bu tür oyun salonlarına kendi yapılarında yer vererek Türk gençlerinin bu oyunlarla daha fazla zaman harcamalarına neden olmuşlardır.

\subsection{Doğa ve Evrenle İlgili Bilgi ve Uygulamalar}

SOKÜM bu başlık altında halk hekimliği, halk mutfağı, halk mimarisi, halk takvimi gibi doğa ve evrenle ile ilgili uygulamaları korumayı esas alır. Bununla ilgili olarak öğrencilere halk takvimi ile ilgili olarak aşağıdaki soru yöneltilmiştir.

Şekil 14: Doğa ve Evren İle İlgili Bilgi ve Uygulamalar

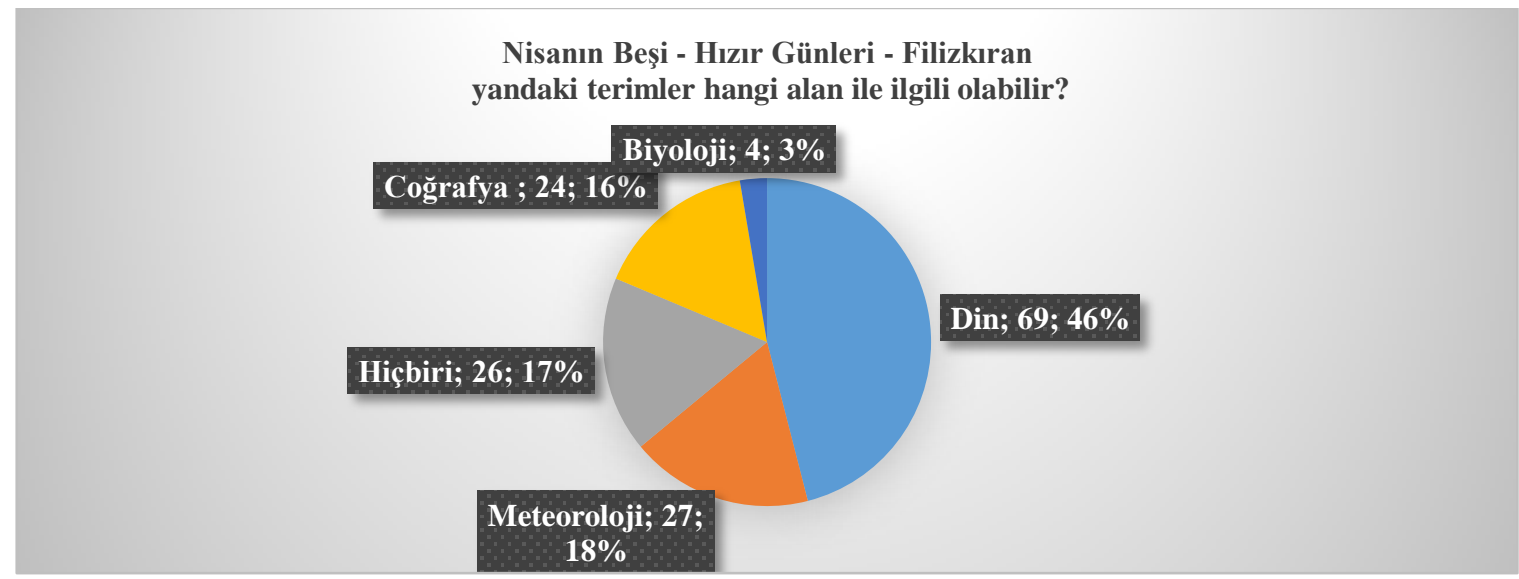


Halk takvimleri, binlerce yıllık doğa-insan birlikteliğinin deneyimi ile oluşmuşlardır. Y1lı, Hızır Günleri ve Kasım Günleri olmak üzere altışar aylık iki büyük bölüme ayıran Türk halk takvimlerinin her bir bölümü binlerce ylllı doğa deneyimi ile belirlenmiştir. Öğrencilerimize halk takviminden meteoroloji ile ilgili üç farklı dönemi içeren soruyu sorduğumuzda Hızır kelimesinin dinî mahiyetinden dolayı cevaplar "Din" cevabı üzerinde yoğunlaşmıştır. Sadece 27 öğrencimiz bu terimlerin ne ile ilgili olduğunu doğru bilmişlerdir.

\subsection{El Sanatları}

SOKÜM'ün en önemli alanlarından biri el sanatlarının yaygınlaştırılması ile ilgilidir. Bununla ilgili olarak, öğrencilere en bilindik el sanatları hakkında bilgi sahibi olup olmadikları soruldu.

Şekil 15: El Sanatları

Aşağıdaki mesleklerden hangisi veya hangileri hakkında bilgi sahibisiniz?

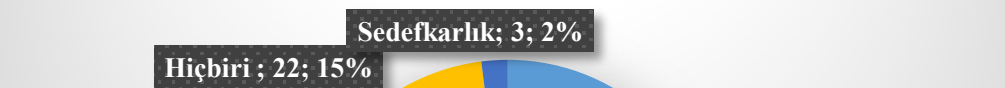

Oya İslemeciliği; $52 ; 34 \%$

Gönen Meslek Yüksekokulunda bulunan programlardan biri "El Sanatları" programıdır. Bu çerçevede sedefkârlık dışındaki el sanatlarını programın öğrencileri bilmektedir. Fakat programın dışında kalan öğrenciler ne yazık ki el sanatları konusunda yeterli bilgiye sahip değiller.

\section{Sonuç ve Öneriler}

UNESCO'nun hazırladığı Somut Olmayan Kültürel Miras sözleșmesi kültürel bellek, ortak deneyim, tarihsel süreklilik ve yaşatarak koruma çerçevesinde ulusların tek tipleşmesini engellemek ve yerel kültürleri güçlendirmeyi hedefler. Sözleşmeye taraf olan ülkelere bu konuda sorumluluklar yükler. Ülkemizin gençlerinin bu kültürel ögeleri içselleştirmeleri ve ilerideki sosyal, siyasi, sanatsal, sportif, ekonomik, dinî hayatlarını bu çerçevede yaşamaları hayati bir zorunluluktur. Fakat anketten aldığımız sonuçlara göre büyük aksaklıkların yaşandığı ortadadır. Bunun için aile, eğitim kurumları ve devlete büyük işler düşmektedir.

Ferdin birey olduğunun farkına varması ve toplumsallığa ilk adımlarını atması aile ortamında gerçekleşir. Ebeveynler, çocuklarını yetiştirirken millî değerleri önceleyen bir anlayışa sahip olmak zorundadırlar. 21. yüzyılda, ailenin millî değerlerle oluşturduğu daireden ayrılacak çocuğu, çok cazip olan fakat onu kimliksizleştirecek, hissizleştirecek, hiçleştirecek ve birçok yabancı değerlerle örülü bir dünya beklemektedir. Çocukların ve gençlerin en büyük problemlerinden birisi Türk kültürüne ve diline ön yargıyla yaklaşmalarıdır. Bu ön yargı 
muhakkak öncelikle aile daha sonra da eğitimciler tarafından ortadan kaldırılmalı, diğer uygarlıklar kadar güçlü bir kültür dairesine sahip olunduğu hissettirilmeli ve büyük Türk kültür dairesine sahip olmanın önemi kavratılmalıdır.

Sözleşmenin eğitime ilişkin öngörüleri bağlamında Türkiye'nin somut olmayan kültürel mirasın korunmasına yönelik örgün eğitim alanında gerçekleştirdiği ilk ve olumlu adım "Halk Kültürü" adlı dersin ilköğretim programlarına konulmasıdır. (Kutlu, 2013: 47). Ama maalesef bu dersler seçmeli olarak konulmuştur. Türk edebiyatı ders kitapları, millî kültürün korunması, tanıtılması ve geliştirilmesi bakımından çok önemlidir. Her yıl ortalama üç buçuk milyon öğrenciye bu ders kitapları aracılığıyla ulaşılmaktadır. Bu bağlamda öğrenciye ulaşma imkânının bu kadar fazla olduğu bir durumda Talim ve Terbiye Kurulu başkanlığı daha dikkatli davranmak zorundadır (Sağlam ve Solmaz, 2011: 634). Bu dersler ilköğretimlerle kalmamalı, BOLOGNA süreci çerçevesinde ders programlarını düzenleyen, programlarına havuz derslerini ilave eden üniversiteler bu havuz dersleri arasına kültürel miras derslerini koymalıdırlar.

"Gençlerin kültürel yabancılaşmasında değişik faktörlerin rolü vardır, bunlar arasında örnek şahsiyetlerin yetersizliği gençlerle ilgili meseleleri kendi kültürel ve dini bağlamlarında ifade etme firsatlarının azalmış olması yer almaktadır. Kültürel bakımdan, batılı gençleri temsil eden ürünler ile genelde Batılı olmayan kesimleri hedef alan ürünler arasında büyük bir dengesizlik bulunmaktadır. $\mathrm{Bu}$ durum gençlerin kendileri ve kültürleri hakkındaki görüşlerini de olumsuz bir şekilde etkilemektedir" (Medeniyetler İttifakı: Yüksek Düzeyli Grup Raporu 13 Kasım 2006). Bu bağlamda üniversiteler tarafindan düzenlenen bahar şenliklerinde, lise ve dengi okulların hazırladıkları yılsonu etkinliklerinde Türk Kültürüne ait hatırlama figürlerine yer vermelidir. Ama maalesef halen ülkemizde Yunus Emre adına Kaşgarlı Mahmud adına, Fatih Sultan Mehmet adına, üniversitelerimiz yoktur. Eğitim kurumlarının bina, salon, kütüphane gibi mekânlarının adları yine bu hatırlama figürlerinden seçilmelidir. Eğitim kurumlarındaki öğrenciler el sanatkârlarıyla tanıştırılmalı, düzenli geziler gerçekleştirilmelidir. Canlı müzeler yaygınlaştırılmalıdır.

Sorumluluğun üçüncü ama belki de en önemli sahibi devlettir. Devletimiz geniş bir bakış açısıyla çocuklar ve gençler için millî kültürel değerleri önceleyen, tanıtan politikalar üretmelidir. Devletin bekası, kültürel değerlerini referans alan gençlerin başarılarıyla mümkündür. $\mathrm{Bu}$ çerçeve de devletler gerek yasaklamalar gerekse de teşviklerle akılcı politikalar üretmek zorundadır. Örnekse bilindiği gibi küreselleşme ve millî değerleri yaşayamamanın temel nedenlerinden biri teknoloji ve medyadır. Bu çerçeve medyanın Türk kültürünü önceleyen programları yapmaları devlet tarafından teşvik edilmelidir. Her gün belirli saatlerde, gençlerin nasıl giyinmesi gerektiğini bilinçaltına işlemeye çalışan yarışmalardan evlilik programlarına, yukarıda anketlerde bahsettiğimiz yabancı değerleri önceleyen dizi filmlerden çeşitli eğlence programlarına kadar birçok program genç dimağlara yerleştirilmektedir. $\mathrm{Bu}$ durumda devletin bazen de yasaklamalar getirmesi zorunludur.

Yerel yöneticilerin kültürel değerleri öncelemeleri çok önemlidir. Her şehrin kendine ait kültürel belleğini yaşatması ve çocukların, gençlerin bu bellekle ve kent imgeleriyle tanıştırılması sağlanmalıdır. Bunların yaşaması için somutlaştırılarak sürekliliğinin tesis edilmesi gerekir. Bu yüzden belediyeler, millî kültürel değerlerin yaşatılması için gerekli çalışmaları yapmak zorundadır.

Bir milletin muasır medeniyetler seviyesine ulaşmasının en temel yolunun, bireylerin millî kültürel değerleri içselleştirerek yüzyıllara uyum sağlaması olduğu asla unutulmamalıdır. Bu durumda aile, eğitim ve devlet üçlüsünün bunu gerçekleştirmesi zorunludur. 


\section{KAYNAKÇA}

ARSLAN, Mustafa (2006a). Küreselleşme ve Yerellik İkileminde Buldan Halk Kültürü. Buldan Sempozyumu Bildirileri. s.711-715.

ARSLAN, Mustafa (2006b). Küreselleşme Sürecinde Kültürün Trajedisi ve Türk Kültürü. I. UIuslararası Türk Dünyası Kültür Kurultayı. Çeşme/İzmir.

BARBER, R. Benjamin (2013). Cihad McDünyaya Karş1: Küreselcilik ve Kabilecilik Dünyayı Nasıl Yeniden Şekillendiriyor?, Küreselleşme, Kültür, Medeniyet. (Çev. Haluk Özdemir). (Editör: Kudret Bülbül). Ankara: Orient Yayınları, s. 92-112.

BÜLBÜL, Kudret (2013). Kültür ve Medeniyet Tartışmalarına Türkiye'den Bakmak. Küreselleşme, Kültür, Medeniyet. (Editör: Kudret Bülbül). Ankara: Orient Yayınları, s.4-26.

COŞKUN, Nilgün Çıblak, ZÖHRE, Harika (2014). Küreselleşme ve Tüketim Kültürünün Yaygınlaşması Bağlamında Türkiye'de Cadılar Bayramı. Turkish Studies - International Periodical For The Languages, Literature and History of Turkish or Turkic Volume 9/3 Winter 2014, s.497-506, Ankara.

EKİCI, Metin (2008). Geleneksel Kültürü Güncellemek Üzerine Bir Değerlendirme. Millî Folklor Dergisi, Say1 80, s.33-38.

EKİCI, Metin, FEDEKAR Pınar (2013). Ege Üniversitesi Deneyimleriyle Somut Olmayan Kültürel Mirası Yaşatarak Koruma. Millî Folklor Dergisi, Sayı 100, s.50-60.

HUNGTINGTON, Samuel (2013). Medeniyetler Çatışması mı?. (Çev. Mustafa Çalık). Küreselleşme, Kültür, Medeniyet. (Editör: Kudret Bülbül). Ankara: Orient Yayınlar1, s.208-232.

KALB, Don, VAN DER LAND, Marco (2013). Mozayiğin Ötesi: Küreselleşen Bir Çağda Kültürel Kimliğin Sorgulanması. (Çev. Zekeriya Tüysüz). Küreselleşme, Kültür, Medeniyet, (Editör: Kudret Bülbül). Ankara: Orient Yayınları, s.26-36.

KAYSERILİ, Mehmet Emin, SATIR, Memduha (2013). Küreselleşme Sürecinin Ulusal Kültür ve Sanata Etkisi. Atatürk Üniversitesi Türkiyat Araştırmaları Enstitüsü Dergisi. Say1 50, s.306-318.

KUŞÇU, Ertan (2015). Fransızca Öğretimi Kişi Betimlemelerinde Kullanılan Deyimlerin Anadil Türkçedeki Görüntüleri. Turkish Studies International Periodical for the Languages, Literature and History of Turkish or Turkic, Volume 10/16 Fall 2015, s.937-952.

KUTLU, Mustafa Muhtar (2013). SOKÜM ve Örgün Eğitim: Halk Kültürü Dersi Deneyimi. Somut Olmayan Kültürel Mirasın Geleceği Türkiye Deneyimi. Ankara: Grafiker Yayınları. s.47-51.

LIEBER, Robert, WEİSBERG, Ruth (2013). Küreselleşme, Kültür ve Kimlik Krizi. Küreselleşme, Kültür, Medeniyet. (Çev. ve Editör: Kudret Bülbül). Ankara: Orient Yayınlar1, s.112-138.

MAZRUI, A. Ali (2013). Evrensellik İddiası: Küreselleşen Bir Çağda Batı Kültürü. (Çev. Hakan Arıkan). Küreselleşme, Kültür, Medeniyet. (Editör: Kudret Bülbül). Ankara: Orient Yayınları. 
OĞUZ, Öcal (2001). Küreselleşme ve Ulusal Kalıt Kavramları Arasında Türk Halk Bilimi. Millî Folklor, Say1 50, s.5-9.

OĞUZ, Öcal (2009). Somut Olmayan Kültürel Miras ve Kültürel İfade Çeşitliliği. Millî Folklor, Say1 82, s.6-13.

OĞUZ, Öcal (2013a). Somut Olmayan Kültürel Miras Nedir? Ankara: Geleneksel Yayıncilik.

OĞUZ, Öcal (2013b). Sunuş. Somut Olmayan Kültürel Mirasin Geleceği Türkiye Deneyimi, Ankara: Grafiker Yayınları, s.5-6.

ÖNAL, Mehmet Naci (2005). Muğla Efsaneleri. Muğla: Muğla Üniversitesi Yayınları.

ÖNAL, Mehmet Naci (2011). Muğla Masalları. Muğla: Muğla Üniversitesi Yayınları.

SAĞLAM, Soner, SOLMAZ, Erhan (2011). Orta Öğretim Türk Edebiyatı Ders Kitaplarında Somut Olmayan Kültürel Mirastan Yararlanılması Üzerine Bir Değerlendirme. IV. Uluslararası Dünya Dili Türkçe Sempozyumu Bildirileri. C2. S. 631-634. Muğla.

TEKE, Selcan Gürçayır (2013a). Geleneksel Tarzlar, Modern Modeller: Resmî, Resmî Olmayan Eğitim ve Somut Olmayan Kültürel Miras. Millî Folklor Dergisi. Say1 100. s.31-39.

TEKE, Selcan Gürçayır (2013b).UNESCO, Gençlik ve Somut Olmayan Kültürel Miras. Somut Olmayan Kültürel Mirasin Geleceği Türkiye Deneyimi. Ankara: Grafiker Yayınlar1. s.73-76. 